\title{
Pengaruh Pijat Bayi Terhadap Lama Tidur Bayi Usia 3-6 Bulan di Desa Jemawan Kecamatan Jatinom Kabupaten Klaten
}

\author{
Devi Dwi Kurniasari ${ }^{1}$, Henik Istikhomah ${ }^{2 *}$, Siswiyanti $^{3}$ \\ ${ }^{1,2,3}$ Poltekkes Kemenkes Surakarta \\ *Email : janeetaqueen@gmail.com
}

\begin{abstract}
Background: Sleep is prime priority for baby, because when this moment occurs repair neuro-brain and more or less $75 \%$ of growth hormone are produced. Considering the importance of sleep time for baby development, baby's sleep needs must be fulfilled in order not to adversely affect growth and development. One of the way to fulfill baby's sleep needs is baby massage. When baby massaged will increase serotonin secretion that will suppress the activity of the reticulation-activating system and causing sleepy. Purpose this study to knowing the effect of baby massage to the length of sleep of baby ages 3-6 month in Jemawan Village, Jatinom Sub-District, Klaten District. Methods: Quasy eksperiment research with one group pretest-posttest design. Sampling using saturated sampling technique with 32 babies. Bivariate analysis using non parametric statistic Wilcoxon test with an error rate of 5\%. Baby massage is performed of baby ages 3-6 month throughout the baby's body for 30 minutes, baby massage is doing 2 times a week in 4 weeks.Results: This study show results that the length of sleep of baby before doing massage is mostly less than 13 hours as much as 18 babies (56,25\%) and the length of sleep of baby after doing massage is normal 13-15 hours as much as 27 babies (84,38\%). The result of Wilcoxon test is $p=0,000(p<0,05)$ that Ha accepted.Conclusion: There is effect of baby massage to the length of sleep of baby ages 3-6 month in Jemawan Village, Jatinom Sub-District, Klaten District.
\end{abstract}

Keywords: baby massage, length of sleep of baby

\section{PENDAHULUAN}

Tidur merupakan salah satu stimulus bagi proses tumbuh kembang otak. Hal ini bisa dimengerti karena $75 \%$ hormon pertumbuhan dikeluarkan saat anak tidur. Hormon pertumbuhan inilah yang merangsang pertumbuhan tulang dan jaringan. Selain itu hormon pertumbuhan juga memungkinkan tubuh memperbaiki dan memperbarui seluruh sel yang ada ditubuh, kulit, sel darah, sampai sel saraf otak (Kelly, 2001).

Tidur adalah salah satu bentuk adaptasi bayi terhadap lingkungannya. Bayi usia 0-5 bulan akan menjalani hidup barunya dengan $80-90 \%$ tidur. Seorang bayi yang baru lahir sampai kira-kira usia 3 bulan, akan menghabiskan waktu tidurnya sekitar 15-17 jam, dengan pembagian waktu 8 jam untuk tidur siang dan 9 jam untuk tidur malam. Semakin usia bayi bertambah, jam tidurnya juga semakin berkurang. Pada bayi usia 3-6 bulan total waktu tidur berkisar antara 1315 jam/hari dan bayi usia 6 bulan pola tidurnya mulai tampak mirip dengan orang dewasa (Gola, 2009).

Saat ini berbagai terapi telah dikembangkan, baik terapi farmakologis maupun non farmakologis. Menurut Prasadja (2009) dalam Roesli (2016) salah satu terapi non farmakologis untuk mengatasi masalah tidur bayi adalah pijat bayi. Penelitian yang dilakukan Tiffany Field di Touch Research Institute Amerika yang menunjukkan bahwa anak-anak yang dipijat selama $2 \times 15$ menit setiap minggunya, tidurnya menjadi lebih nyenyak sehingga pada waktu bangun konsentrasinya lebih baik daripada sebelum diberi pemijatan. 
Pemijatan akan meningkatkan meningkatkan kapasitas sel reseptor yang berfungsi mengikat glucocortiroid sehingga terjadi penurunan kadar hormon adrenalin. Hormon serotonin merupakan zat penghantar syaraf yang berpengaruh terhadap munculnya perasaan nyaman dan optimis, relaksasi, perasaan bugar, kemampuan memfokuskan konsentrasi dan perhatian, dan dorongan untuk makan (Apriadji, 2007).

Pijat bayi merupakan terapi sentuh yang paling tua, yang dibutuhkan bagi kebutuhan dasar pada bayi. Sentuhan yang diberikan kepada bayi dengan penekanan lembut akan menimbulkan rasa aman dan nyaman. Jika sentuhan dan pijat bayi diberikan secara rutin segera setelah kelahiran bayi, adalah sebuah kontak kelanjutan tubuh bayi yang dibutuhkan oleh bayi untuk mempertahankan rasa aman dan nyaman bayi. Ketika bayi dipijat akan menimbulkan rasa aman dan nyaman maka dapat meningkatkan sekresi serotonin yang akan menekan aktivitas sistem pengaktivasi retikularis dan mengakibatkan kantuk (Riksani, 2012).

Berdasarkan studi pendahuluan yang dilakukan oleh peneliti pada tanggal 28 Agustus 2019 di Posyandu Desa Jemawan, dengan mewawancarai dari 6 ibu yang memiliki bayi usia 3-6 bulan, diperoleh hasil 3 orang ibu mengatakan bahwa bayinya sering terbangun pada malam hari lebih dari satu jam, total jumlah tidur perhari kurang dari 13 jam, dan 3 orang ibu mengatakan tidak ada gangguan tidur pada bayinya yang mempunyai jumlah jam tidur normal dengan rata-rata 14 jam perhari. Bayi yang belum mempunyai jam tidur yang cukup, keesokan harinya bangun tidur dengan kondisi tidak segar, seringkali menguap, menangis, bahkan rewel. Berdasarkan data diatas aktivitas neurotransmiter serotonin, yaitu menunjukkan bahwa masih banyak bayi yang belum mempunyai jam tidur yang cukup.

Penelitian ini bertujuan untuk mengetahui pengaruh pijat bayi terhadap lama tidur bayi usia 3-6 bulan di Desa Jemawan Kecamatan Jatinom Kabupaten Klaten.

\section{METODE PENELITIAN}

Jenis penelitian ini adalah penelitian kuantitatif dengan pendekatan quasy eksperiment. Penelitian ini dilakukan di Desa Jemawan, Kecamatan Jatinom, Kabupaten Klaten, dilaksanakan pada Agustus-Desember 2019.

Populasi penelitian ini adalah bayi usia 3-6 bulan di Desa Jemawan, Kecamatan Jatinom, Kabupaten Klaten pada bulan November-Desember 2019 sebanyak 32 bayi, jumlah sampel didapat sebanyak 32 responden. Pengambilan sampel dengan teknik total sampling. Instrumen yang digunakan pada penelitian ini adalah lembar observasi.

Jenis data yang digunakan dalam penelitian ini adalah data primer. Pengumpulan data dilakukan dengan memberikan lembar observasi kepada ibu bayi dan meminta ibu bayi untuk mengisi dengan lengkap lembar observasi yang telah disediakan. Pengisian lembar observasi dilakukan sendiri oleh ibu bayi dengan menuliskan jumlah tidur bayi dalam jam perhari dan setiap pemijatan bayi peneliti mengonfirmasi ulang berapa lama tidur bayinya.

Dalam penelitian ini etichal clearance dilakukan untuk meningkatkan kualitas penelitian yang diberikan oleh RSUD Dr. Moewardi Surakarta selaku Komisi Etik Penelitian yang menyatakan bahwa penelitian ini layak dilaksanakan 
setelah memenuhi persyaratan tertentu. Inform consent diberikan pada ibu bayi yang bayinya memenuhi kriteria sampel penelitian untuk memberikan persetujuan kebersediaannya menjadi responden penelitian. Analisis data pada penelitian ini menggunakan analisis univariat yang digambarkan dalam bentuk distribusi frekuensi dan bivariat dengan uji Wilcoxon.

\section{HASIL PENELITIAN}

Hasil penelitian menunjukkan karakteristik responden seperti tergambar pada tabel 1.

Tabel 1. Umur, Jenis Kelamin, dan Konsumsi Bayi

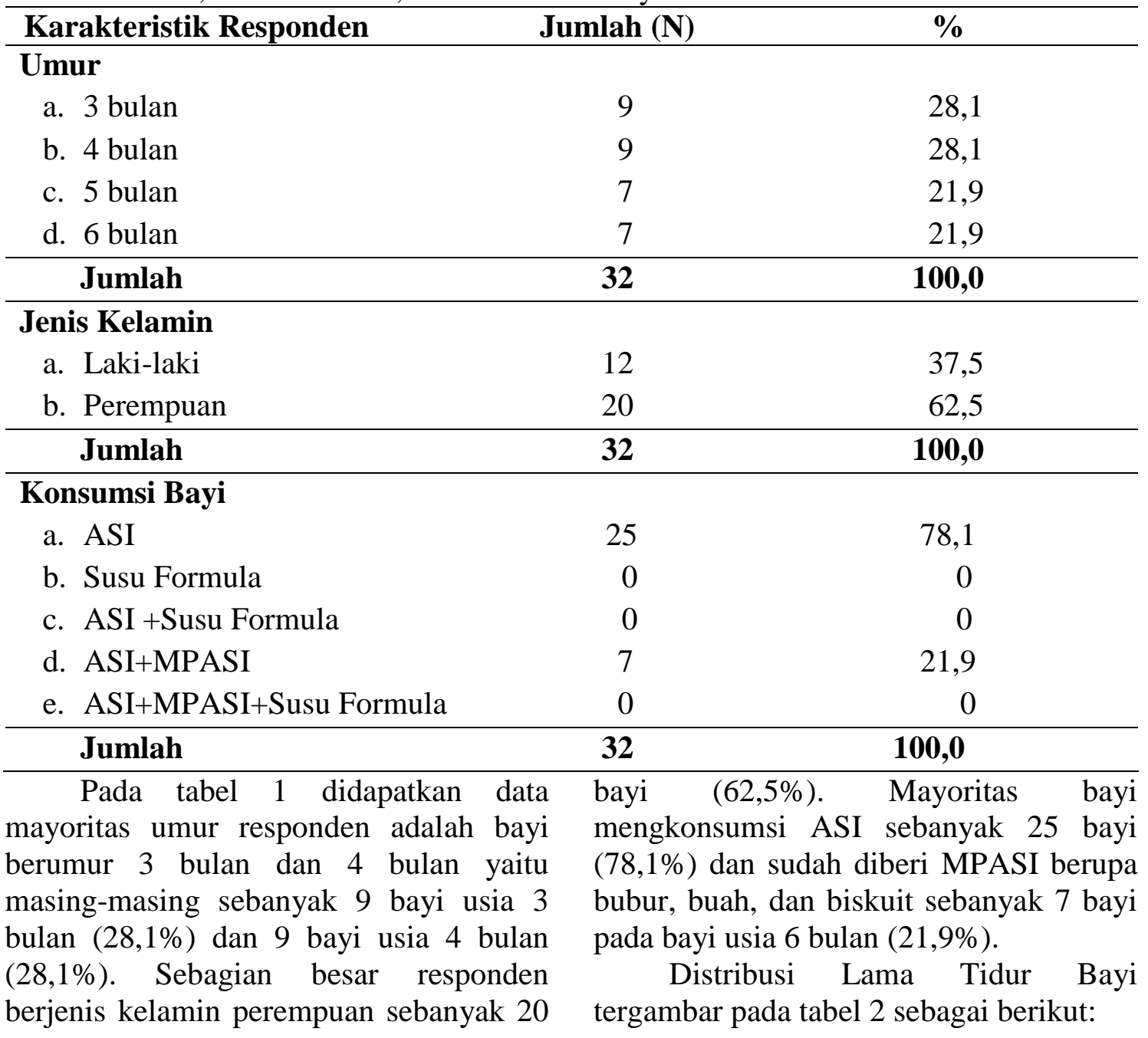


Tabel 2. Lama Tidur Bayi Usia 3-6 Bulan Sebelum dan Sesudah Pemijatan

\begin{tabular}{lccccc}
\hline \multirow{2}{*}{ Lama Tidur Bayi } & \multicolumn{3}{c}{ Pretest } & \multicolumn{3}{c}{ Postest } \\
\cline { 2 - 6 } & Jumlah $(\mathbf{N})$ & Persen (\%) & Jumlah (N) & Persen (\%) \\
\hline Kurang (<13 jam) & 18 & 56,25 & 0 & 0,0 \\
Normal (13-15 jam) & 14 & 43,75 & 27 & 84,4 \\
Lebih (>15 jam) & 0 & 0,0 & 5 & 15,6 \\
\hline Total & $\mathbf{3 2}$ & $\mathbf{1 0 0}$ & $\mathbf{3 2}$ & $\mathbf{1 0 0}$ \\
\hline Pada tabel & didapatkan & data & Lamanya tidur & bayi setelah \\
sebagian besar tidur bayi sebelum & dilakukan pemijatan sebagian besar tidur \\
dilakukan pemijatan memiliki lama tidur & bayi memiliki lama tidur normal yaitu 27 \\
yang kurang yaitu sebanyak 18 bayi & bayi (84,4\%) dan bayi yang memiliki \\
(56,25\%) dan tidak ada bayi yang & lama tidur yang lebih yaitu 5 bayi \\
memiliki lama tidur yang lebih. & (15,6\%).
\end{tabular}

Tabel 3. Perbedaan Rata-rata Lama Tidur Bayi Usia 3-6 Bulan Sebelum dan Sesudah Pemijatan

\begin{tabular}{lcccc}
\hline \multicolumn{1}{c}{ Variabel } & Jumlah (N) & Min & Max & Mean \\
\hline $\begin{array}{l}\text { Lama tidur bayi usia 3-6 bulan sebelum } \\
\text { pemijatan }\end{array}$ & 32 & 10 & 13 & 11,73 \\
\hline $\begin{array}{l}\text { Lama tidur bayi usia 3-6 bulan sesudah } \\
\text { pemijatan }\end{array}$ & 32 & 13,5 & 15,8 & 14,35 \\
\hline $\begin{array}{l}\text { Pada tabel 3 didapatkan data } \\
\text { didapatkan rata-rata lama tidur sebelum } \\
\text { pemijatan yaitu 11,73 jam/hari dan } \\
\text { ratarata sesudah dilakukan pemijatan }\end{array}$ & $\begin{array}{l}\text { adalah 14,35 jam/hari. } \\
\text { pengaruh pijat bayi terhadap lama tidur } \\
\text { bayi usia 3-6 bulan tergambar pada } \\
\text { tabel 4. }\end{array}$
\end{tabular}

Tabel 4. Pengaruh Pijat Bayi Terhadap Lama Tidur Bayi Usia 3-6 Bulan

\begin{tabular}{|c|c|c|c|c|c|c|}
\hline \multirow[b]{2}{*}{ Lama Tidur Bayi } & \multicolumn{2}{|c|}{ Pretest } & \multicolumn{2}{|l|}{ Postest } & \multirow[b]{2}{*}{$Z$} & \multirow[b]{2}{*}{$P$} \\
\hline & Jumlah (N) & $\%$ & Jumlah (N) & $\%$ & & \\
\hline ) & & 56 & & 0 & & \\
\hline ) & 1 & 43 & 27 & 8 & & \\
\hline 15 jan & 0 & , & 5 & 15,6 & & \\
\hline Total & 32 & 100 & 32 & 100 & & \\
\hline \multicolumn{3}{|c|}{$\begin{array}{l}\text { Berdasarkan tabel } 4 \text { di atas terlihat } \\
\text { bahwa sebagian besar tidur bayi sebelum } \\
\text { dilakukan pemijatan memiliki lama tidur } \\
\text { yang kurang yaitu sebanyak } 18 \text { bayi } \\
(56,25 \%) \text { dan tidak ada bayi yang } \\
\text { memiliki lama tidur yang lebih. Lamanya } \\
\text { tidur bayi setelah dilakukan pemijatan } \\
\text { sebagian besar tidur bayi memiliki lama } \\
\text { tidur normal yaitu } 27 \text { bayi }(84,4 \%) \text { dan }\end{array}$} & \multicolumn{4}{|c|}{$\begin{array}{l}\text { bayi yang memiliki lama tidur yang lebih } \\
\text { yaitu } 5 \text { bayi }(15,6 \%) \text {. } \\
\text { Hasil analisis data dengan uji } \\
\text { wilcoxon diperoleh nilai } \mathrm{Z}-4,955 \text { dengan } \\
p \text { value (Asymp. Sig } 2 \text { tailed) sebesar } \\
0,000 \text { maka } p \text { value }<0,05 \text { sehingga Ho } \\
\text { ditolak dan Ha diterima artinya ada } \\
\text { perbedaan lama tidur bayi sebelum dan } \\
\text { sesudah pemijatan. }\end{array}$} \\
\hline
\end{tabular}


Dengan hasil tersebut, maka hipotesis dalam penelitian ini diterima yang berarti ada pengaruh pijat bayi terhadap lama tidur bayi usia 3-6 bulan di Desa Jemawan, Kecamatan Jatinom, Kabupaten Klaten.

\section{PEMBAHASAN}

Penelitian yang telah dilakukan di Desa Jemawan, Kecamatan Jatinom, Kabupaten Klaten dengan 32 responden diperoleh hasil bahwa sebagian besar umur pada bayi usia 3-6 bulan di Desa Jemawan yang diberikan pijat bayi adalah umur 3 bulan dan 4 bulan yaitu masingmasing sebanyak 9 bayi usia 3 bulan dan 9 bayi usia 4 bulan. Menurut Roesli (2016) bayi akan mendapatkan keuntungan yang lebih besar jika dipijat dari sejak kelahiran hingga usia 6-7 bulan. Pada usia 3 bulan sampai 3 tahun, pemijatan dilakukan dengan menggunakan tekanan pada seluruh gerakan dan waktunya semakin meningkat. Menurut Gola (2009), semakin usia bayi bertambah, jam tidurnya juga semakin berkurang, pada usia 3-6 bulan jumlah total waktu tidur berkisar antara 13-15 jam/hari. Maka dapat disimpulkan bahwa umur bayi 3 sampai 6 bulan memiliki karakteristik yang sama dalam hal lama tidur dan pemijatan.

Sebagian besar bayi mengkonsumsi hanya ASI yaitu 25 bayi dan hasil pretest didapatkan sebanyak 14 bayi memiliki lama tidur normal. Hal ini sesuai dengan Potter dan Perry (2013) bahwa ASI terbukti mengandung alfa protein yang kaya asam amino essensial, terutama triptofan. Triptofan adalah asam amino yang berperan dalam proses neurotransmitter dan pengatur pola hidup (nuerobehaviorl) dimana salah satu fungsinya adalah mengatur pola tidur. Jadi dapat disimpulkan bahwa konsumsi bayi juga mempengaruhi tidur bayi.

Berdasarkan hasil dari penelitian ini, perubahan lama tidur sebelum dan sesudah diberi pemijatan mengalami perubahan dengan selisih 2,62 jam/hari. Hal ini terbukti dari hasil rata-rata lama tidur sebelum dilakukan pemijatan adalah $11,73 \mathrm{jam} /$ hari dan rata-rata lama tidur bayi setelah dilakukan pemijatan adalah 14,35 jam/hari. Hal ini menunjukan adanya peningkatan lama tidur bayi setelah dilakukan pemijatan. Hal ini sesuai dengan teori Subakti dan Anggarani (2008), bayi yang otot-ototnya distimulasi dengan pemijatan akan nyaman dan mengantuk. Bayi akan tidur lebih lama, selain lama, bayi nampak tidur terlelap. Hal ini menunjukan bahwa bayi merasa tenang setelah dipijat.

Lamanya tidur bayi sebelum dilakukan pemijatan adalah kurang dari normal sebanyak 18 bayi dan sisanya memiliki lama tidur normal yaitu 14 bayi. Lama tidur bayi setelah diberi perlakuan pemijatan mayoritas menjadi normal sebanyak 27 bayi dan yang memiliki lama tidur lebih dari 15 jam sebanyak 5 bayi. Setelah diberi pemijatan, sudah banyak bayi yang memiliki lama tidur normal 1315 jam dan ada yang lama tidurnya lebih dari 15 jam. Pada bayi yang memiliki kuantitas tidur lebih dari 15 jam ini hanya kelebihan beberapa menit saja dan tidak membahayakan bagi bayi. Paling banyak memiliki kelebihan 50 menit dan paling sedikit kelebihan 10 menit. Hal ini sesuai dengan Subakti dan Anggarani (2008), bahwa kebanyakan bayi akan tidur dengan waktu yang lama begitu pemijatan usai dilakukan kepada bayi. Menurut Roesli 
(2016), bayi yang dipijat akan tertidur lebih lelap, sedangkan pada waktu bangun konsentrasinya akan lebih penuh.

Berdasarkan hasil uji dengan uji Wilcoxon berdasarkan tabel 4.4 diperoleh nilai signifikansi $(p)$, dimana diketahui nilai $p=0,000$, sehingga dapat disimpulkan bahwa $p<0,05$. Berarti $\mathrm{Ha}$ diterima sehingga ada pengaruh pijat bayi terhadap lama tidur bayi usia 3-6 bulan. Menurut Potter dan Perry (2013) peningkatan jumlah lama tidur bayi ini dikarenakan saat dilakukan pemijatan terjadi sekresi serotonin yang merupakan zat transmitter utama yang menyertai pembentukan tidur dengan menekan aktivitas sistem retikulasi maupun otak lainnya. Serotonin yang disintesis dari asam amino tripthophan akan diubah menjadi 5-hidroksitriptophan (5HTP) kemudian menjadi $\mathrm{N}$-asetil serotonin yang pada akhirnya berubah menjadi melatonin, sehingga bayi akan tertidur setelah dilakukan pemijatan.

Hasil ini serupa dengan penelitian yang dilakukan oleh Sri Sudarsih dan Wahyu L.Y (2015) dengan judul Pengaruh Pijat Bayi Terhadap Kuantitas Tidur Bayi Usia 3-6 Bulan di Desa Leminggir Kecamatan Mojosari Kabupaten Mojokerto dengan hasil nilai $p=0,002$ berarti ada pengaruh pijat bayi terhadap kuantitas tidur bayi usia 3-6 bulan.

Hasil ini juga serupa dengan penelitian yang dilakukan oleh Pamungkas (2016) didapatkan hasil dengan uji Chi Square pengaruh pijat bayi terhadap kualitas tidur bayi, disimpulkan bahwa terdapat pengaruh pijat bayi dengan kualitas tidur bayi. Nilai Odd ratio (OR) uji sebesar 15,00 artinya bayi yang dengan pijat bayi berpeluang memiliki kualitas tidur yang baik 15 kali lebih tinggi dibandingkan bayi yang tidak mendapatkan pijat bayi.

Didukung juga dengan hasil penelitian yang dilakukan oleh Warsini dan Nugraini (2016) dengan judul Pengaruh Pijat Bayi Terhadap Lama Tidur Bayi di Desa Duwet Kecamatan Wonosari Kabupaten Klaten dengan hasil penelitian diketahui bahwa pada kelompok bayi yang diberi tindakan pijat memiliki ratarata lebih tinggi $(15,90$ jam/hari) daripada rata-rata kuantitas tidur kelompok bayi yang tidak diberi pijat $(13,90$ jam/hari). Kesimpulan dari penelitian ini adalah terdapat pengaruh pijat bayi dengan lama tidur bayi.

Menurut Kelly (2001), tidur merupakan prioritas utama bagi bayi, karena pada saat inilah repair neuro-brain dan kurang lebih $75 \%$ hormon pertumbuhan diproduksi. Mengingat akan pentingnya waktu tidur bagi perkembangan bayi, maka kebutuhan tidurnya harus terpenuhi agar tidak berpengaruh buruk terhadap pertumbuhan dan perkembangannya. Salah satu cara yang dapat memenuhi kebutuhan tidur bayi adalah dengan pijat bayi. Ketika bayi dipijat akan meningkatkan sekresi serotonin yang akan menekan aktivitas sistem pengaktivasi retikularis dan akan mengakibatkan kantuk.

Dalam penelitian ini dapat disimpulkan bahwa lamanya tidur bayi setelah dilakukan pijat bayi erat hubungannya dengan pengoptimalan tumbuh kembang anak. Mengingat banyak sekali manfaat tidur bagi bayi, maka pijat bayi yang dilakukan secara teratur dan rutin dapat dijadikan salah satu alternatif untuk meningkatkan lama tidur bayi. 


\section{KESIMPULAN DAN SARAN}

Berdasarkan hasil penelitian dapat disimpulkan bahwa karakteristik responden di Desa Jemawan, Kecamatan Jatinom, Kabupaten Klaten berdasarkan usia bayi yang diteliti dalam penelitian ini sebagian besar bayi berumur 3 bulan dan 4 bulan masing-masing sebanyak 9 bayi usia 3 bulan $(28,1 \%)$ dan 9 bayi usia 4 bulan $(28,1 \%)$. Mayoritas jenis kelamin bayi pada penelitian ini adalah bayi perempuan berjumlah 20 bayi $(62,5 \%)$. Pada penelitian ini mayoritas bayi mengkonsumsi ASI sebanyak 25 bayi $(78,1 \%)$ dan sudah diberi MP-ASI berupa bubur, buah, dan biskuit sebanyak 7 bayi $(21,9 \%)$ pada bayi usia 6 bulan.

Lama tidur usia 3-6 bulan sebelum perlakuan pijat bayi (pretest) diperoleh hasil paling banyak adalah kurang dari 13 jam sebanyak 18 (56,25\%) bayi. Rata- rata lama tidur bayi sebelum perlakuan pijat bayi adalah 11,73 jam.

Lama tidur usia 3-6 bulan setelah pemijatan (posttest) diperoleh hasil paling banyak adalah normal 13-15 jam sebanyak $27(84,38 \%)$ bayi. Rata-rata lama tidur bayi setelah perlakuan pemijatan adalah 14,27 jam.

Dari hasil uji statistika dengan menggunakan uji Wilcoxon diperoleh nilai $p$ value $(0,000<0,05)$ berarti ada pengaruh pijat bayi terhadap lama tidur bayi usia 3-6 bulan di Desa Jemawan, Kecamatan Jatinom, Kabupaten Klaten.

Hasil pada penelitian ini didapat bahwa pijat bayi berpengaruh pada lama tidur bayi usia 3-6 bulan. Mengingat banyak sekali manfaat tidur bagi bayi, diharapkan adanya pijat bayi dapat dijadikan salah satu alternatif untuk meningkatkan lamanya tidur bayi.

Bagi Tenaga Kesehatan diharapkan tenaga kesehatan khususnya bidan dapat memberikan informasi serta melatih dan mendemonstrasikan metode pijat bayi atau menyarankan kepada masyarakat untuk memijat bayinya sedini mungkin ke tenaga kesehatan yang sudah terlatih, serta menjadikan pijat bayi sebagai bagian dari program kesehatan bayi untuk mengoptimalkan tumbuh kembang.

Bagi orangtua responden diharapkan ibu-ibu dapat melanjutkan pemijatan anaknya dengan mempelajari pijat bayi agar dapat memijat sendiri di rumah secara teratur dan rutin sehingga bayi tidak mengalami gangguan tidur dan dapat tumbuh serta berkembang dengan optimal. Bagi institusi pendidikan diharapkan penelitian ini dapat dijadikan referensi penelitian yang dapat digunakan dalam ilmu pengetahuan.

\section{DAFTAR RUJUKAN}

A.A \& Uliyah, M. (2008). Kebutuhan Dasar Manusia. Jakarta: Buku Kedokteran EGC.

Abata, Qorry 'Aina. (2015). Merawat Bayi Baru Lahir. Madiun: Yayasan PP AlFurqon.

Adi, Nuri Purwito dan Rini Sekartini. (2006). Gangguan Tidur pada Anak Usia Bawah Tiga Tahun di Lima Kota Indonesia. Jurnal Sari Pediatri, Vol. 7, No.4, Maret 2006: 188-193.

Apriadji, W. H. (2007). Good Mood Food. Jakarta: Gramedia Pustaka Utama.

Ardhillah, City, Azz. (2012). Segalanya Bayi, Kupas Tuntas Ilmu Bayi A-Z. Yogyakarta: Syura Mediautama.

Bintang Aji Pamungkas. (2016). 
Pengaruh Pijat Bayi terhadap Kualitas Tidur Bayi Umur 0-6 Bulan di Puskesmas Kartasura. Surakarta: Universitas Muhammadiyah Surakarta.

Cahyaningrum dan Sulistyorini, E.(2014). Hubungan Pijat Bayi Terhadap Kualitas Tidur Bayi Umur 0-3 Bulan di RB Suko Asih Sukoharjo Tahun 2013. Surakarta: Akbid Mamba'ul 'Ulum Surakarta.

Chaerunnis, Firsta Nodia. (2017). Hindari Memijat Bayi di Tiga Bagian Tubuh Ini. Diakses pada tanggal 22 Agustus 2019.

Dari https://www.suara.com/health/2017/11/ 07/143143/hindarimemijatbayi-ditigabagian-tubuh-ini

Charlotte C. Yates, Anita J, Mitchell, Melisa Y. Booth, D.Keith Williams, Leah M. Lowe, and Richard Whit Hall. (2015). The Effects of Massage Therapy to Induce Sleep in Infants Born Preterm. Pediatr Phys Ther. Winter; 26(4): 405-410.

Conny, Tanjung, M. F dan Rini Sekartini. (2004). Masalah Tidur pada Anak. Sari Pediatri, 6 (3), 138-142.

Gola, G. (2009). Ayo Bangun! Dengan Bugar karena Tidur yang Benar. Jakarta: Penerbit Hikmah.

Handayani, dkk. (2015). Pengaruh Pijat Bayi terhadap Kualitas Tidur Bayi Usia 3-5 Bulan di Desa Plalangan Kecamatan Kalisat. Program S1 Keperawatan Fakultas Ilmu Kesehatan Universitas Muhammdiyah Jember. Jember: UMJ.

Hansen Kent, Shriver Tim, et al.,.
(2005). The Effects of Exercise on the Storage and Oxidation of Dietary Fat., Department of Nutritional Sciences, University of Wisconsin-Madison USA. (ejournal) diakses 22 Agustus 2019; available at http://www.ingentaconnect.com/content/a dis/smd/2005/00000035/00000005/art000 $\underline{01}$

Kelly, Paula.(2001). Bayi Anda Tahun Pertama. Jakarta: Arcan.

Kenner, C.,\& McGrath,J.M. (2004). Developmental Care of Newborn \& Infants: A Guidefor Health Proffessionals. St. Louis: Mosby.

Mardiana, L dan Martini, D. E. (2014). Pengaruh Pijat Bayi Terhadap Kuantitas Tidur Bayi Usia 3-6 Bulan di Desa Munungrejo Kecamatan Ngimbang Kabupaten Lamongan. Surya, 2 (18). 109-115.

Maryunani, Anik. (2010). Ilmu Kesehatan Anak. Jakarta: CV. Trans Info Media.

Notoatmodjo.(2012). Metodologi Penelitian Kesehatan. Jakarta: Rineka Cipta.

Nursalam. (2014). Metodologi Penelitian Ilmu Keperawatan. Jakarta: Salemba Medika.

Potter, P. A dan Perry, A. G. (2013). Fundamentals of Nursing Eighth Edition. Canada: Elsevier.

Prasetyono. (2009). Teknik-teknik Tepat Memijat Bayi Sendiri Panduan Lengkap dan Uraian Kemanfaatannya. Yogyakarta: Diva Press. 
Putra, S.R. (2012). Asuhan Neonatus Bayi dan Balita untuk Keperawatan dan Kebidanan. Yogyakarta: D-Medika.

Riksani, R. (2012). Cara Mudah dan Aman Pijat Bayi. Jakarta: Niaga Swadaya.

Roesli, Utami. (2016).Pedoman Pijat Bayi. Jakarta: PT. Trubus Agriwidya.

Sadeh, I dan Zion, M. (2011). Which Type of Inquiry Project Do High School Biology Student Prefer.

Saryono.(2011).Metode Penelitian Kesehatan. Yogyakarta: Mitra Cendekia Press.

Siregar, Syofian. (2013). Metode Penelitian Kuantitatif. Jakarta: Kencana Prenada Media Group.

Subakti, Y dan Anggarani, D. R. (2008). Keajaiban Pijat Bayi dan Balita. Jakarta: Wahyu Media.

Sugiyono. (2016). Metode Penelitian Kuantitatif Kualitatif dan $R \& D$. Bandung: Alfabeta.

Warsini dan Nugraini, D. (2016). Pengaruh Pijat Bayi Terhadap Lama Tidur Bayi di Desa Duwet Kecamatan Wonosari Kabupaten Klaten. Kosala JIK, 4 (1), 83-89. 